\title{
GAMBARAN SKOR MMSE, CDT, TMT A DAN TMT B PADA LANSIA DI PANTI WERDHA AGAPE TONDANO
}

\author{
${ }^{1}$ Reza B. Susanto \\ ${ }^{2}$ Rizal Tumewah \\ ${ }^{2}$ Arthur H. P. Mawuntu
}

\author{
${ }^{1}$ Kandidat Skripsi Fakultas Kedokteran Universitas Sam Ratulangi Manado \\ ${ }^{2}$ Bagian Neurologi, Fakultas Kedokteran Universitas Sam Ratulangi Manado \\ Email: rsusanto_11_068@ymail.com
}

\begin{abstract}
Indonesia has the highest growth of elderly population. Health problem that often occurs in the elderly is impaired cognitive function which can be examined by using various examinations. Rapid examinations with practical high values are Mini Mental State Examination (MMSE), Clock Drawing Test (CDT), as well as Trail Making Test A and B (TMT A and B). These are done by giving a series of commands to a person and then his/her accuracy will be assessed. This was a cross-sectional study conducted from December 2014 to January 2015 at the Agape elderly nursing home Tondano. The results showed that there were 12 respondents that met the inclusion criteria consisted of eight females and four males. The results of the four tests showed that MMSE had $67 \%$ of respondents with normal cognitive function, CDT had $75 \%$ with normal executive function, TMT A had 100\% with experienced executive interference, and TMT B had 92\% with experienced executive interference. Conclusion: Most respondents showed MMSE with normal cognitive function and CDT with, normal executive function, however, all respondents showed TMT A with experienced executive interference, and nearly all respondents showed TMT $\mathrm{B}$ with experienced executive interference. Cognitive dysfunction were more frequent among the elderly of $\geq 75$ years, female, primary school education, and unemployment.
\end{abstract}

Keywords: elderly, cognitive function, executive function

\begin{abstract}
Abstrak: Indonesia merupakan negara tertinggi dalam pertumbuhan penduduk lanjut usia. Peningkatan jumlah penduduk lanjut usia tersebut menimbulkan masalah kesehatan, masalah kesehatan yang sering terjadi pada usia lanjut antara lain gangguan fungsi kognitif. Gangguan fungsi kognitif ini dapat di periksa dengan berbagai pemeriksaan. Pemeriksaan yang cepat dan praktis namun nilainya tinggi adalah pemeriksaan Mini Mental State Examination (MMSE), Clock Drawing Test (CDT), Trail Making Test A dan B (TMT A dan B). Pemeriksaan ini dilakukan dengan memberi serangkaian perintah pada seseorang dan ketepatannya dinilai. Penelitian ini menggunakan desain potong lintang, dilakukan pada bulan Desember 2014 hingga Januari 2015 bertempat di Panti Werdha Agape Tondano. Hasil penelitian mendapatkan 12 responden yang memenuhi kriteria penelitian, terdiri dari 8 perempuan dan 4 laki-laki. Hasil pemeriksaan MMSE menunjukkan 67\% responden dengan fungsi kognitif normal, CDT menunjukkan 75\% dengan fungsi eksekutif normal, TMT A menunjukkan 100\% dengan gangguan eksekutif, dan TMT B menunjukkan 92\% mengalami gangguan eksekutif. Simpulan: Sebagian besar responden menunjukkan hasil pemeriksaan MMSE dengan fungsi kognitifnya normal, CDT dengan fungsi eksekutif normal, sedangkan untuk TMT A seluruh responden mengalami gangguan eksekutif, dan TMT B hampir seluruh responden mengalami gangguan eksekutif. Secara keseluruhan, gangguan fungsi kognitif lebih banyak pada lansia perempuan usia $\geq 75$ tahun, pendidikan SD, dan tidak bekerja.
\end{abstract}

Kata kunci: lansia, fungsi kognitif, fungsi eksekutif 
Indonesia merupakan negara tertinggi dalam pertumbuhan penduduk lanjut usia dalam kurun waktu 1990-2010. Hal tersebut menghantarkan Indonesia menjadi negara keempat negara berpenduduk lanjut usia terbanyak di dunia setelah China, India, dan Amerika Serikat. ${ }^{1}$

Di Indonesia sendiri pada tahun 2000, jumlah lansia meningkat mencapai 9,99\% dari seluruh penduduk Indonesia (22.277.700 jiwa) dengan umur harapan hidup usia 65-70 tahun dan pada tahun 2020 di perkirakan akan mencapai 30 juta orang dengan umur harapan hidup 70-75 tahun (Badan Penelitian Statistik).

Di seluruh dunia, 35,6 juta orang memiliki demensia, dengan lebih dari setengah (58 \%) yang tinggal di negaranegara berpenghasilan rendah dan menengah. Setiap tahun, ada 7,7 juta kasus baru. Jumlah ini akan berlipat ganda pada 2030 dan lebih dari tiga kali lipat pada tahun 2050 (WHO, 2012).

Menurut Depkes RI (1999), pengertian lansia adalah seseorang yang berusia 60 tahun keatas. Sedangkan menurut UU Kesejahteraan Lanjut Usia No 13 tahun 1998, lansia adalah seseorang yang telah mencapai usia 60 tahun keatas, baik pria maupun wanita, masih mampu melakukan pekerjaan dan atau kegiatan yang dapat menghasilkan barang dan/atau jasa ataupun tidak berdaya mencari nafkah sehingga hidupnya bergantung pada bantuan orang lain.

Peningkatan jumlah penduduk lanjut usia tersebut menimbulkan berbagai masalah sosial, ekonomi, dan kesehatan. Beberapa masalah kesehatan yang sering terjadi pada usia lanjut antara lain gangguan fungsi kognitif dan keseimbangan., ${ }^{2,3}$

Gangguan fungsi kognitif ini dapat di periksa dengan berbagai pemeriksaan. Pemeriksaan yang cepat dan praktis namun nilainya tinggi adalah pemeriksaan Mini Mental State Examination (MMSE), Clock Drawing Test (CDT), Trail Making Test A dan B (TMT A \& B). Pemeriksaan ini dilakukan dengan memberi serangkaian perintah pada seseorang dan menilai ketepatannya. $^{2}$

Penelitian ini adalah untuk mengetahui gambaran skor MMSE, CDT, TMT A dan TMT B pada lansia di Panti Werdha Agape Tondano.

\section{METODE PENELITIAN}

Penelitian ini merupakan studi potong lintang yang dilakukan di Panti Werdha Agape Tondano sejak bulan Desember 2014 sampai Januari 2015. Populasi penelitian adalah lansia penghuni panti Werdha Agape Tondano. Pada penelitian ini, jumlah penghuni Panti Werdha berjumlah 29 orang, diantara 29 orang hanya didapati 27 orang yang memenuhi kriteria inklusi, dari 27 orang ada 15 orang yang dieksklusi, jadi berdasarkan kriteria penelitian, peneliti hanya mendapatkan 12 responden dari 29 penghuni tetap panti Werdha Agape Tondano. Responden diperiksa dengan pemeriksaan MMSE, CDT, TMT A \& B, untuk pemeriksaan TMT A \& B dilakukan rehearsel terlebih dahulu, dan data yang diperoleh diolah dengan menggunakan SPSS dan Excel.

\section{HASIL PENELITIAN}

\section{Karakteristik Pasien}

Distribusi jenis kelamin responden yang terbanyak ialah perempuan $(66,7 \%)$ dibandingkan laki-laki (33,3\%) (Tabel 1).

Tabel 1. Distribusi Responden Berdasarkan Jenis Kelamin

\begin{tabular}{ccc}
\hline Jenis Kelamin & Jumlah & $\%$ \\
\hline Laki-laki & 4 & $33,3 \%$ \\
Perempuan & 8 & $66,7 \%$ \\
\hline Total & 12 & $100,0 \%$ \\
\hline
\end{tabular}

Distribusi umur responden yang terbanyak pada umur $\geq 75$ tahun (75\%). Dalam penelitian ini rentang umur responden 23 tahun (66-89 tahun) dengan rerata 76,5 \pm 6,24 tahun (Tabel 2). Distribusi pendidikan 
terakhir responden terbanyak ialah SD (66,7\%) (Tabel 3). Distribusi pekerjaan terakhir responden terbanyak ialah tidak bekerja (75\%) (Tabel 4).

Tabel 2. Distribusi Responden Berdasarkan Umur

\begin{tabular}{ccc}
\hline Umur & Jumlah & $\%$ \\
\hline 60-74 Tahun & 3 & 25,0 \\
$\geq 75$ Tahun & 9 & 75,0 \\
\hline Total & 12 & 100,0 \\
\hline
\end{tabular}

Tabel 3. Distribusi Responden Berdasarkan Pendidikan

\begin{tabular}{ccc}
\hline $\begin{array}{c}\text { Pendidikan } \\
\text { Terakhir }\end{array}$ & Jumlah & $\%$ \\
\hline SD & 8 & 66,7 \\
SMP & 1 & 8,3 \\
SMA & 1 & 8,3 \\
>SMA & 2 & 16,7 \\
\hline Total & 12 & 100,0 \\
\hline
\end{tabular}

Tabel 4. Distribusi Responden Berdasarkan Pekerjaan

\begin{tabular}{ccc}
\hline Pekerjaan & Jumlah & $\%$ \\
\hline Tidak Bekerja & 9 & 75,0 \\
IRT & 0 & 0,0 \\
Pedagang & 0 & 0,0 \\
Wiraswasta & 0 & 0,0 \\
Pensiunan PNS & 1 & 8,3 \\
Pensiunan & 1 & 8,3 \\
Veteran & 0 & 0,0 \\
PNS & 0 & 0,0 \\
Buruh/Tani & 0 & 0,0 \\
TNI/Polri & 1 & 8,3 \\
Penjahit & 12 & 100,0 \\
\hline Total &
\end{tabular}

Pemeriksaan Fungsi Kognitif

Hasil pemeriksaan MMSE menunjukkan yang termasuk dalam kategori normal sebanyak 8 orang (66,6\%), kategori curiga gangguan kognitif sebanyak 2 orang $(16,7 \%)$ dan kategori pasti gangguan kognitif sebanyak 2 orang (16,7\%) (Gambar 1).
Hasil CDT menunjukkan 3 orang (25 $\%)$ termasuk dalam kategori fungsi kognitif terganggu dan 9 orang (75\%) termasuk dalam kategori fungsi kognitif normal (Gambar 2).

Hasil pemeriksaan TMT A menunjukkan bahwa seluruh responden (100\%) mengalami gangguan kognitif.

Hasil pemeriksaan TMT B menunjukkan sebanyak 1 orang termasuk dalam kategori normal dan 11 orang termasuk dalam kategori terganggu.

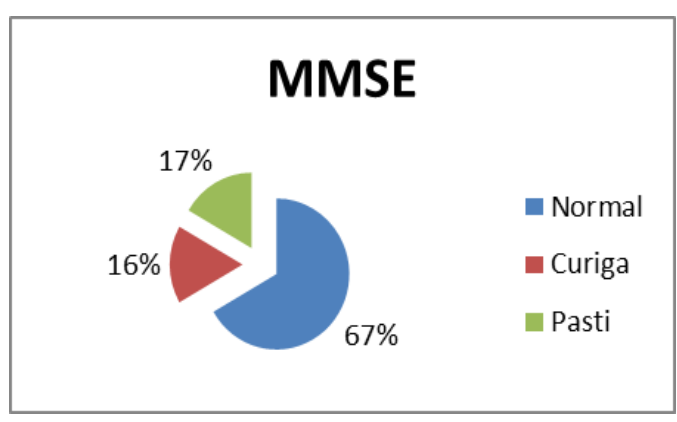

Gambar 1. Diagram Pemeriksaan MMSE

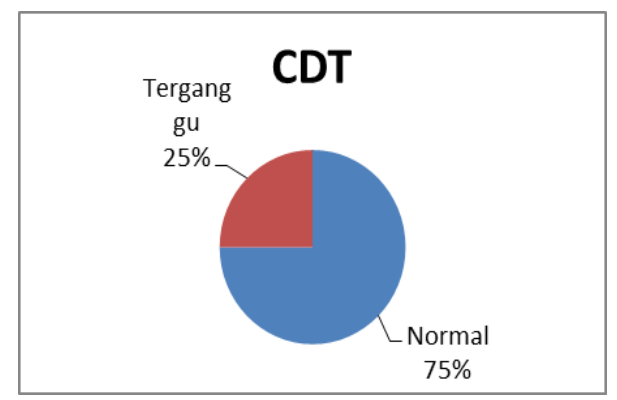

Gambar 2. Diagram Pemeriksaan CDT

\section{BAHASAN}

Penelitian ini dilakukan pada penghuni Panti Werdha Agape Tondano selama bulan Desember 2014 hingga Januari 2015.

Pada penelitian ini, jumlah penghuni Panti Werdha berjumlah 29 orang, diantara 29 orang hanya didapati 27 orang yang memenuhi kriteria inklusi, dari 27 orang ada 15 orang yang dieksklusi, jadi berdasarkan kriteria penelitian, peneliti hanya mendapatkan 12 responden dari 29 
penghuni tetap panti Werdha Agape Tondano.

Pada penelitian ini, hasil CDT dan TMT A \& B menunjukkan jenis kelamin perempuan lebih banyak mengalami gangguan kognitif daripada laki-laki, pada pemeriksaan MMSE pasti gangguan kognitif sama antara responden laki-laki dan perempuan, sedangkan curiga gangguan kognitif lebih banyak dialami oleh perempuan.

Dari data pemeriksaan CDT dan TMT A \& B dapat dilihat bahwa gangguan kognitif ditemukan lebih banyak pada golongan usia $\geq 75$ tahun, pada pemeriksaan MMSE pasti gangguan kognitif seimbang antara golongan usia 6074 tahun dan golongan usia $\geq 75$ tahun sedangkan curiga gangguan kognitif lebih banyak dialami oleh golongan usia $\geq 75$ tahun. Hal ini sangat sesuai dengan kepustakaan, bahwa umur yang semakin meningkat mengakibatkan perubahan anatomi, seperti semakin menyusutnya otak, dan perubahan biokimiawi di SSP sehingga dengan sendirinya bisa menyebabkan terjadinya penurunan fungsi kognitif. ${ }^{4,5}$

Pada hasil pemeriksaan MMSE, CDT, TMT A \& B menunjukkan bahwa tingkat pendidikan SD mengalami gangguan kognitif terbanyak, pada pemeriksaan MMSE curiga gangguan kognitif seimbang antara pendidikan SD dan S1.

Pada penelitian ini, hasil pemeriksaan MMSE berdasarkan pekerjaan menunjukkan bahwa yang mengalami gangguan kognitif setara antara yang tidak bekerja dan pensiunan PNS dan curiga gangguan kognitif lebih banyak pada yang tidak bekerja. Pada pemeriksaan TMT A dan TMT B berdasarkan pekerjaan menunjukkan bahwa yang mengalami gangguan kognitif lebih banyak pada yang tidak bekerja, sedangkan hasil pemeriksaan CDT menunjukkan bahwa yang mengalami gangguan kognitif seimbang antara penjahit, pensiunan veteran, dan pensiunan PNS.
Dari hasil CDT yang didapat menunjukkan 3 orang (25\%) termasuk dalam kategori fungsi kognitif terganggu dan 9 orang (75\%) termasuk dalam kategori fungsi kognitif normal. Hasil pemeriksaan CDT memiliki persamaan dengan pemeriksaan MMSE yaitu sebagian besar memiliki hasil yang normal, hasil ini juga sesuai dengan pernyataan CDT menunjukkan korelasi yang baik dengan tes kognitif yang lain yaitu MMSE (Henderson, Scot, \& Hotopf, 2007). ${ }^{6}$

Berdasarkan hasil TMT A menunjukkan bahwa $100 \%$ responden mengalami gangguan kognitif, sedangkan hasil TMT B menunjukkan bahwa 92 \% responden mengalami gangguan kognitif.

\section{SIMPULAN}

Berdasarkan hasil penelitian dapat disimpulkan bahwa sebagian besar responden menunjukkan hasil pemeriksaan MMSE dengan fungsi kognitifnya normal, CDT dengan fungsi eksekutif normal, sedangkan untuk TMT A seluruh responden mengalami gangguan eksekutif, dan TMT B hampir seluruh responden mengalami gangguan eksekutif. Secara keseluruhan, gangguan fungsi kognitif lebih banyak pada lansia perempuan usia $\geq$ 75 tahun, pendidikan SD, dan tidak bekerja.

\section{SARAN}

Disarankan perlu dilakukan penelitian lanjutan dengan sampel yang lebih besar baik di rumah sakit maupun di tempat lain, untuk mendeteksi fungsi kognitif. Selain itu, perlu dilakukan skrining dengan pemeriksaan MMSE, CDT, TMT A \& B untuk mendeteksi adanya gangguan kognitif, dan kegiatan-kegiatan yang bermanfaat dalam melatih perkembangan kognitif.

\section{DAFTAR PUSTAKA}

1. Martono, Heru. Gerakan Nasional [homepage on the internet]. c2008 [cited 2014 Oct 5]. Available from: 
http://www.gemari.or.id/file/edisi88/g emari8933 .pdf

2. Hesti, Harris S, Mayza A, Prihartono J. Pengaruh Gangguan Kognitif Terhadap Gangguan Keseimbangan Pada Lanjut Usia. Neurona.2008;25:26-31.

3. Setiati S, Harimurti K, Arya RG. Proses menua dan implikasi kliniknya. Dalam: Sudabyo AW, Setiyohadi B, Alwi I, Simadibrata M, Setiati S. Buku ajar ilmu penyakit dalam. Ed 5. Jilid I. Jakarta: Pusat Penerbitan Departemen IPD FKUI; 2009.p. 757-
60.

4. Martono H, Pranarka K. Buku Ajar Boedhi-Darmojo Geriatri (Ilmu Kesehatan Usia Lanjut) Edisi ke-4. Balai Penerbit Jakarta: FK UI; 2010.

5. Kandel, Schwartz, Jessell. Principles of Neural Sciences Fifth Edition. USA: McGraw-Hill; 2000.

6. Hartati S, Widayanti CG. Clock Drawing: Asesmen untuk demensia (study deskriptif pada orang lanjut usia di kota Semarang. Jurnal Psikologi Undip. Volume 7. No 1. April 2010. 